\title{
ISOLATED FAMILIAL SOMATOTROPINOMA: 11Q13-LOH AND GENE/PROTEIN EXPRESSION ANALYSIS SUGGESTS A POSSIBLE INVOLVEMENT OF AIP ALSO IN NON-PITUITARY TUMORIGENESIS
}

\author{
Rodrigo A. Toledo, ${ }_{\text {I Berenice B. Mendonca, }}^{\text {II } M a r i a ~ C a n d i d a ~ B . ~ V . ~ F r a g o s o, ~}{ }^{\text {II }}$ Iberê C. Soares, ${ }^{\text {III }}$ Madson Q. Almeida ${ }^{\mathrm{II}}$, Michelle B. \\ Moraes, ${ }^{\mathrm{I}}$ Delmar M. Lourenço-Jr, ${ }^{\mathrm{I}}$ Venâncio A. F. Alves, ${ }^{\mathrm{III}}$ Marcello D. Bronstein, ${ }^{\mathrm{IV}}$ Sergio P. A. Toledo ${ }^{\mathrm{I}}$
}

\author{
doi: $10.1590 / \mathbf{S 1 8 0 7 - 5 9 3 2 2 0 1 0 0 0 0 4 0 0 0 1 0}$
}

Toledo RA, Mendonca BB, Fragoso MCBV, Soares IC, Almeida MQ, Moraes MB. et al. Isolated familial somatotropinoma: 11q13-loh and gene/protein expression analysis suggests a possible involvement of AIP also in non-pituitary tumorigenesis. Clinics. 2010;65(4):407-15.

OBJECTIVE: Non-pituitary tumors have been reported in a subset of patients harboring germline mutations in the aryl hydrocarbon receptor-interacting protein $(A I P)$ gene. However, no detailed investigations of non-pituitary tumors of $A I P$-mutated patients have been reported so far.

PATIENTS: We examined a MEN1 - and p53-negative mother-daughter pair with acromegaly due to somatotropinoma. Subsequently, the mother developed a large virilizing adrenocortical carcinoma and a grade II B-cell non-Hodgkin's lymphoma.

DESIGN: Mutational analysis was performed by automated sequencing. Loss-of-heterozygosity (LOH) analysis was carried out by sequencing and microsatellite analysis. AIP expression was assessed through quantitative PCR (qPCR) and immunohistochemistry. RESULTS: The functional inactivating mutation c.241C $>\mathrm{T}$ (R81X), which blocks the AIP protein from interacting with phosphodiesterase 4A (PDE4A), was identified in the heterozygous state in the leukocyte DNA of both patients. Analyzing the tumoral DNA revealed that the AIP wild-type allele was lost in the daughter's somatotropinoma and the mother's adrenocortical carcinoma. Both tumors displayed low AIP protein expression levels. Low AIP gene expression was confirmed by qPCR in the adrenocortical carcinoma. No evidence of LOH was observed in the DNA sample from the mother's B-cell lymphoma, and this tumor displayed normal AIP immunostaining.

CONCLUSIONS: Our study presents the first molecular analysis of non-pituitary tumors in AIP-mutated patients. The finding of $A I P$ inactivation in the adrenocortical tumor suggests that further investigation of the potential role of this recently identified tumor suppressor gene in non-pituitary tumors, mainly in those tumors in which the cAMP and the 11q13 locus are implicated, is likely to be worthwhile.

KEYWORDS: Acromegaly; pituitary tumor; FIPA; AIP; Adrenocortical tumor.

\footnotetext{
I Unidade de Endocrinologia Genética, LIM/25 (RAT, MBM, DML, SPAT), Hospital das Clínicas, Faculdade de Medicina da Universidade de São Paulo - São Paulo/SP, Brazil.

II Unidade de Endocrinologia do Desenvolvimento, Laboratório de Hormônios e Genética Molecular, LIM/42 (BBM, MCBVF, MQA), Hospital das Clínicas, Faculdade de Medicina da Universidade de São Paulo - São Paulo/SP, Brazil.

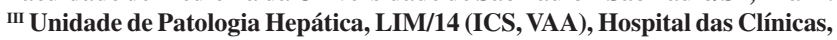
Faculdade de Medicina da Universidade de São Paulo - São Paulo/SP, Brazil. IV Unidade de Neuroendocrinologia (MDB) da Disciplina de Endocrinologia, Hospital das Clínicas, Faculdade de Medicina da Universidade de São Paulo - São Paulo/SP, Brazil.

Tel: 55113061.7226

Email: toledorodrigo@usp.br

Received for publication on March 22, 2010

First review completed on March 25, 2010

Accepted for publication on March 25, 2010
}

\section{INTRODUCTION}

Acromegaly/gigantism is characterized by excess of growth hormone $(\mathrm{GH})$ largely due to $\mathrm{GH}$-secreting pituitary adenomas. ${ }^{1}$ Although most cases are sporadic, familial forms may occur in association with inherited syndromes such as Multiple Endocrine Neoplasia type 1 (MEN1), Carney complex (CNC), pituitary adenoma predisposition (PAP) and familial isolated pituitary adenoma (FIPA), which includes isolated familial somatotropinoma (IFS). ${ }^{2-4}$

Germline mutations and somatic inactivation of the aryl hydrocarbon receptor- interacting protein $(A I P)$ gene 
have been recently identified in patients with PAP. ${ }^{2}$ The role of AIP in FIPA patients has been confirmed, and more than thirty different $A I P$ inactivating mutations have been identified throughout the gene. ${ }^{5}$ GH-, GH/PRL- and PRLsecreting pituitary adenomas are the most common clinical features of AIP mutation carriers, although ACTH-secreting and non-functioning pituitary adenomas have also been reported ${ }^{5,6}$ AIP mutations account for approximately $15 \%$ of families with FIPA and 50\% of IFS families. ${ }^{3,5}$ While AIP mutations appear to be very rare in cases with sporadic pituitary disease, ${ }^{7,8,9}$ they are more frequently found in children and adolescents with GH-secreting tumors, even in the absence of family history. ${ }^{10}$

Although no systematic clinical surveys of non-pituitary neoplasia have been reported, concomitant non-pituitary tumors, including thyroid, adrenal and MEN1-related tumors were reported in a subset of AIP mutation-positive PAP and FIPA families ${ }^{10,11}$ and Prof. Albert Beckers, FIPA Meeting, Liège 2009 (unpublished data). The fact that AIP interacts with phosphodiesterases type 4A (PDE4A) and type 2A (PDE2A) implicates this gene in the cyclic AMP (CAMP) signaling cascade, ${ }^{12,13}$ a cellular pathway known to be disrupted in pituitary, but also in thyroid and adrenal tumorigenesis. ${ }^{14,15}$ Furthermore, AIP is widely expressed, which may argue in favor of a potential involvement of this gene also in non-pituitary tumors. Thus, one may hypothesize that mutations in AIP may also predispose patients to a broader spectrum of endocrine tumors. However, no genetic investigations of non-pituitary tumors in AIP-mutated patients have been performed to date. In this study, we investigated tumoral samples from a somatotropinoma, an adrenocortical carcinoma and a grade II B-cell non-Hodgkin's lymphoma from a motherdaughter pair with IFS who harbor a functional AIP germline mutation.

\section{SUBJECTS}

We investigated the germline and somatic status of AIP in a previously reported Brazilian family (mother-daughter pair) ${ }^{16}$ with early-onset acromegaly (at 25 years and at 14 years, respectively) due to invasive pituitary macroadenomas who have been followed in our institution for the last decade. This family has been recently included in the ongoing genetic screening program for Multiple Endocrine Neoplasia at the Endocrine Genetics Unit laboratory at the University of São Paulo School of Medicine. ${ }^{17-24}$ Since the initial report of a GH-secreting pituitary adenoma, the index case (mother) subsequently developed a virilizing adrenocortical carcinoma and a grade II B-cell non-Hodgkin lymphoma. Because MEN1 and p53 mutations had been previously excluded in this case, ${ }^{16,25}$ we hypothesized that loss of the AIP gene could be implicated.

\section{CLINICAL FEATURES}

The index patient was diagnosed with acromegaly due to a pituitary macroadenoma at 25 years of age (1986). MEN1 and CNC syndromes were ruled out given the absence of the characteristic biochemical and clinical features of these syndromes (such as hyperparathyroidism and enteropancreatic tumors for MEN1 and spotty skin pigmentation, cutaneous myxomas and Cushing's syndrome for $\mathrm{CNC}$ ). She underwent transsphenoidal surgery followed by radiotherapy and exhibited persistently normal basal serum levels of GH and insulin-like growth factor-1 (IGF-1) after surgery. At present (48 years old), GH and IGF-1 levels remain within the normal range, and the pituitary MRI was normal, indicating that she had been cured of her pituitary disease.

Thirteen years after pituitary surgery (1999), she presented with virilization and secondary amenorrhea associated with high serum levels of total testosterone $(538 \mathrm{ng} / \mathrm{dL}$; normal range, $15-80 \mathrm{ng} / \mathrm{dL}$ ) and dehydroepiandrosterone sulfate (DHEA-S) (>10,000 ng/mL; normal range, 350-4300 ng/mL). An abdominal CT scan revealed a large heterogeneous mass $(9.0 \mathrm{~cm} \times 8.9 \mathrm{~cm})$ in the right adrenal gland compressing the vena cava and the lower portion of the liver. The tumor was surgically excised en bloc without rupturing the organ capsule through a classic lobotomy, and right nephrectomy and extensive resection of local lymph nodes were performed. The histopathological analysis ruled out the invasion of local lymph nodes, liver or vena cava, and the tumor was staged as MacFarlane-II and Weiss-III (high nuclear grade, absence of clear cells and diffuse architecture), indicating adrenocortical carcinoma. There has been no biochemical or imaging evidence of tumor recurrence during 10 years of post-surgical follow-up (1999-2009).

At the age of 42 (2001), the patient developed an apparently indolent grade 2 (WHO classification) slowgrowing follicular B-cell non-Hodgkin lymphoma. The immunophenotype was ascertained by immunohistochemical studies of lymph node biopsy samples. The samples were positive for anti-BCL-2, CD10, CD20 and CD68 antibodies and negative for $\mathrm{CD} 3$ (in the follicles).

The patient also presented two solid thyroid nodules of $7 \mathrm{~mm}$ and $11 \mathrm{~mm}$ in size, without adenomegaly, that had been identified in previous cervical ultrasonograms (1999). Pelvic imaging studies (2001) showed ovaries of $5.1 \mathrm{~cm}$ and $7.8 \mathrm{~cm}$, respectively, two ovarian cysts $(4.7 \mathrm{~cm}$ and $5.5 \mathrm{~cm})$ and periaortic, cava-aortic and iliac lymph nodes that were enlarged by up to $2 \mathrm{~cm}$. She underwent a hysterectomy due 
to adenomyosis and an oophorectomy (right ovary) due to enlarged follicle cysts.

\section{Family history}

The index patient has two daughters (dizygotic twins) and one son (Figure 1A). One of the female twins was evaluated at 14 years of age. She was $167 \mathrm{~cm}$ tall and presented with mild acromegaloid features but no signs of gigantism. The GH and IGF-1 serum levels were high, whereas prolactin was normal. An MRI revealed a large pituitary adenoma with suprasellar extension, as well as an invasion of the cavernous and sphenoid sinuses. The tumor was resistant to somatostatin analog therapy. The patient subsequently underwent two transcranial surgeries, one of which involved a transcavernous approach. Histopathological immunohistochemistry analyses indicated that the pituitary adenoma was positive for GH. No clinical and biochemical features of the MEN1 and CNC syndromes were observed in this patient. She has been followed up

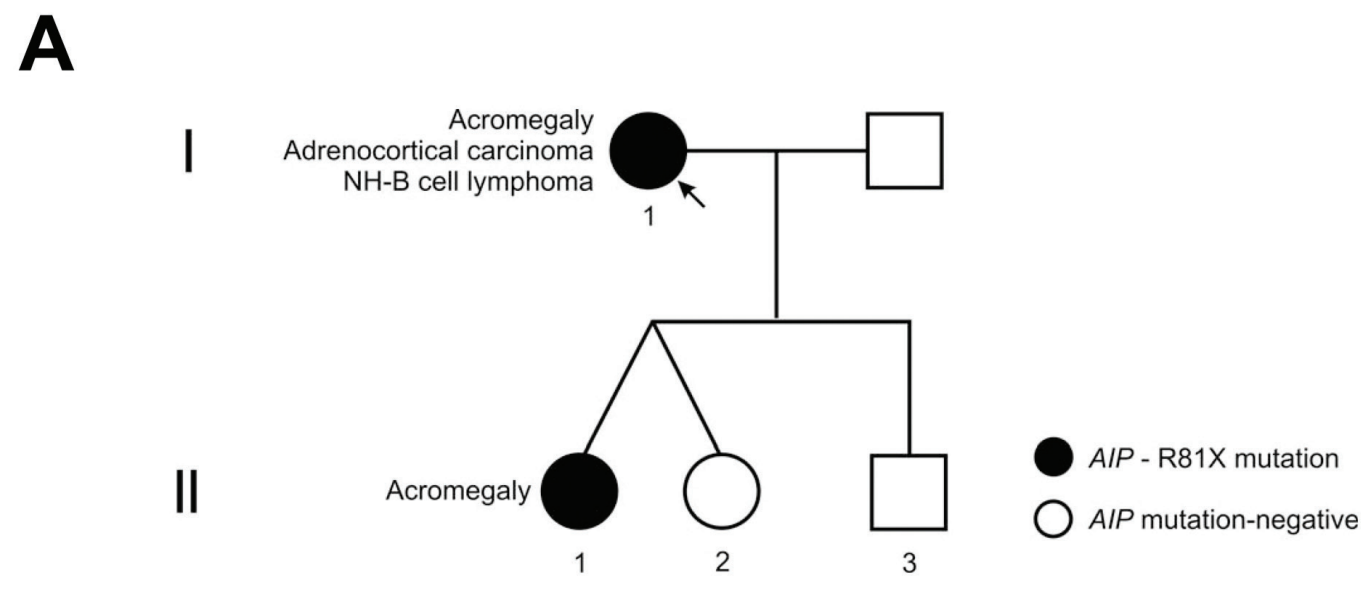

\section{B}

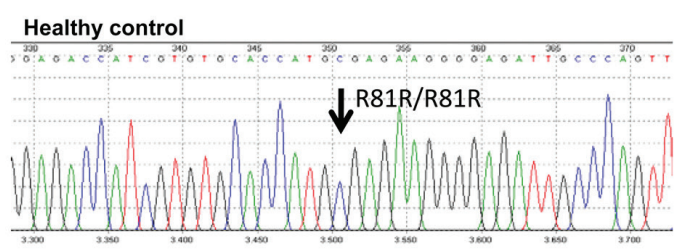

Index-case (mother), blood
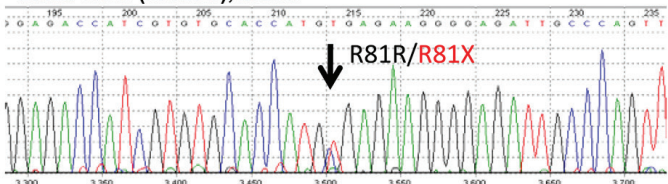

Healthy control

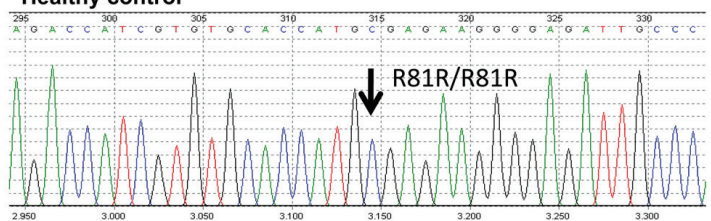

Patient-2 (daughter), blood
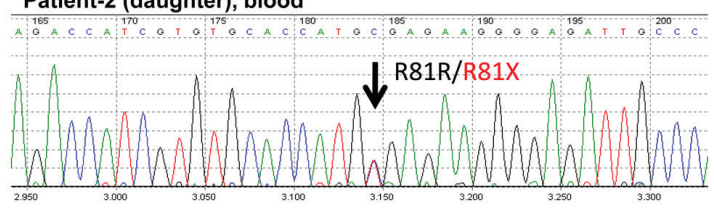

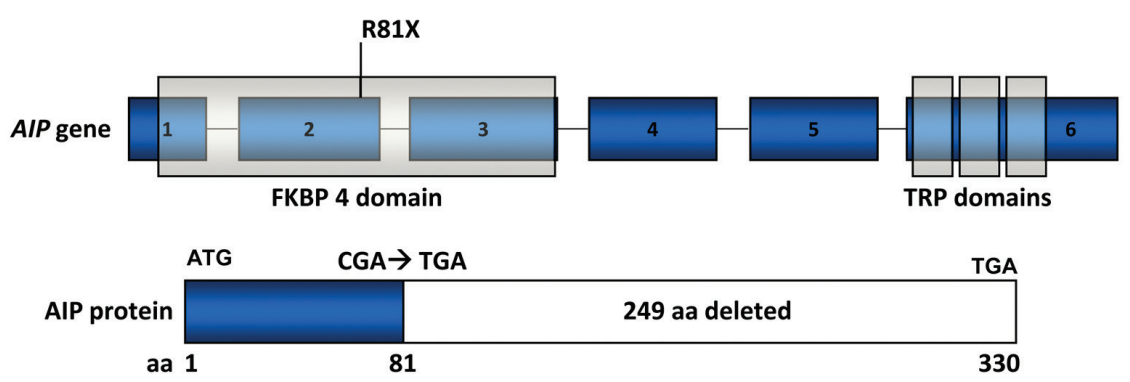

Figure 1 - Genealogy: identification of a functional AIP mutation that may disrupt the cAMP signaling pathway. A - The index patient developed acromegaly, adrenocortical carcinoma and B-cell lymphoma. One of her daughters had acromegaly due to a large and invasive somatotropinoma. B - The known AIP functional mutation c. $241 \mathrm{C}>\mathrm{T}(\mathrm{R} 81 \mathrm{X})^{28}$ was identified in genomic DNA samples from both patients (mother and daughter) with acromegaly but not in the three unaffected family members. 
periodically since 2000, and any adrenal involvement has been ruled out by clinical assessment, determination of adrenal steroid levels and imaging studies (abdominal CT scans). The other female twin and the son were clinically and biochemically normal.

The index patient reported that one of her sisters also exhibited thyroid nodules and that her mother and another sister had ovarian cysts. These individuals were not available for clinical assessment.

\section{GENETIC (NON-AIP) FEATURES}

\section{MEN1 gene}

As previously reported, the index patient did not harbor a germline MEN1 mutation; however, she and her acromegalic daughter share 13 microsatellite loci at chromosomal region $11 \mathrm{q} 13 .{ }^{16}$

\section{$P 53$ gene}

Furthermore, the index patient did not have a germline or somatic R337H TP53 mutation, which is commonly identified in children but less frequently identified in adult patients with adrenocortical neoplasia in southern Brazil. ${ }^{25}$

\section{TUMORS}

Both paraffin blocks and frozen tissue samples of the daughter's GH-secreting pituitary adenoma and the mother's adrenocortical tumor and B-cell non-Hodgkin lymphoma were available for study. Samples from the thyroid and ovarian tissues and the mother's somatotropinoma were not available.

\section{METHODS}

The present study was approved by the local ethics committee (Cappesq) of our institution (protocol 0437/08). All patients and control subjects gave written informed consent.

\section{AIP germline mutation analysis}

Genomic DNA was isolated from the peripheral blood using a standard salting-out protocol, and PCR reactions were performed as previously described. ${ }^{2}$ Both DNA strands were sequenced from purified PCR products using Big Dye Terminator v3.1 (Applied Biosystems, Foster City, CA) and an automated sequencer (ABI Prism 3130xl DNA Analyser, Applied Biosystems).

\section{Loss-of-heterozygosity analysis}

Two different approaches (intragenic and extragenic) were used to verify whether the AIP wild-type allele was lost in the tumors. The mother's somatotropinoma and thyroid neoplasm were not available for study. We performed PCR amplification, automated sequencing and haplotyping analysis using the D11S1258-11q13 microsatellite marker located close $(67,069,747-67,069,958 \mathrm{bp}$, Ensembl) to the AIP gene 11q13.3 locus $(67,007,097-67,015,150 \mathrm{bp}$, Ensembl).

\section{Quantitative mRNA analysis}

A commercially available RNA/cDNA pool of normal adrenals ( $n=61$ ), normal pituitary and normal adrenal tissues obtained from autopsies (Clontech, Palo Alto, CA) were used as controls. Quantitative PCR (qPCR) was performed with an ABI Prism 7700 Sequence Detector using the TaqMan Gene Expression Assays (Hs00610222_m1 for AIP and 43263 for $\beta$-actin) following the manufacturer's instructions (Applied Biosystems). A cycle threshold (CT) value in the linear range of amplification was selected for each sample in triplicate and normalized to the $\beta$-actin expression levels. The relative expression levels were analyzed using the $2^{-\Delta \Delta} \mathrm{CT}$ method, ${ }^{26}$ where $\Delta \Delta \mathrm{CT}$ is the difference between the selected $\Delta \mathrm{CT}$ value of a particular sample and the $\Delta \mathrm{CT}$ of a pool of normal adrenals.

\section{AIP immunohistochemistry}

The slides were deparaffinized, hydrated and subsequently incubated in a $10 \mathrm{mM}$ citrate buffer (pH 6.0) on a steamer for $40 \mathrm{~min}$ at $95^{\circ} \mathrm{C}$. After several washes, each set of slides was incubated overnight with an anti-ARA9/ AIP monoclonal primary antibody (clone 35-2, Novus Biologicals, Littleton, $\mathrm{CO}$ ), and then with the Novolink (Vision Biosystems ${ }^{\mathrm{TM}}$, Victoria, $\mathrm{Au}$ ) secondary peroxidase short polymer system. Detailed information on qPCR and immunohistochemistry protocols can be obtained upon request.

\section{RESULTS}

\section{AIP germline status in the IFS patients}

A heterozygous nucleotide change c.241C $>\mathrm{T}$ (R81X) in exon 2 of AIP was identified in genomic DNA samples from the two acromegaly patients (mother and daughter) (Figure 1). The R81X is a known functional mutation that codes for a truncated protein lacking the tetratricopeptide 
repeat (TPR) carboxy terminal domains, which are essential for AIP to bind to the aryl hydrocarbon receptor (AHR) and heat shock 90 (HSP90). ${ }^{12,27}$ Previous in vitro studies of the R81X mutation have shown that it blocks the interaction of wild type AIP and phosphodiesterase type 4A (PDE4A), potentially disrupting the cAMP cascade..$^{28}$

\section{AIP somatic status in the somatotropinoma, adrenocor- tical tumor and B-cell non-Hodgkin lymphoma}

Sequencing the AIP gene in the tumoral DNA samples revealed a complete loss of the remaining wild-type allele " $\mathrm{C}$ " in both the pituitary and adrenocortical tumors (Figures 2B, 3B). Samples from the adrenocortical tumor and B-cell non-Hodgkin lymphoma were analyzed with the AIPflanking microsatellite marker D11S1258, and LOH was confirmed in the adrenocortical tumor (Figure 3B). However, the lymphoma maintained heterozygosity at the AIP locus (Figure 4).

\section{AIP gene expression in normal adrenals and the adre- nocortical tumor of the IFS $A I P$-mutated patient}

The mean $\mathrm{Ct}$ values of AIP and $\beta$-actin in the pool of normal adrenal samples were 25.42 and 22.49 , respectively, while in the adrenocortical carcinoma of the IFS AIPmutated case, the values were 31.53 and 27.28 , respectively. Using the $2^{-\Delta \Delta} \mathrm{CT}$ method to determine relative expression, we observed decreased AIP expression in the adrenocortical carcinoma in comparison to the pooled normal adrenals $\left(2^{-\Delta \Delta} \mathrm{CT}=0.48\right)$ (Figure 3C). This finding is in accordance with our analysis of the somatic status of AIP, which showed

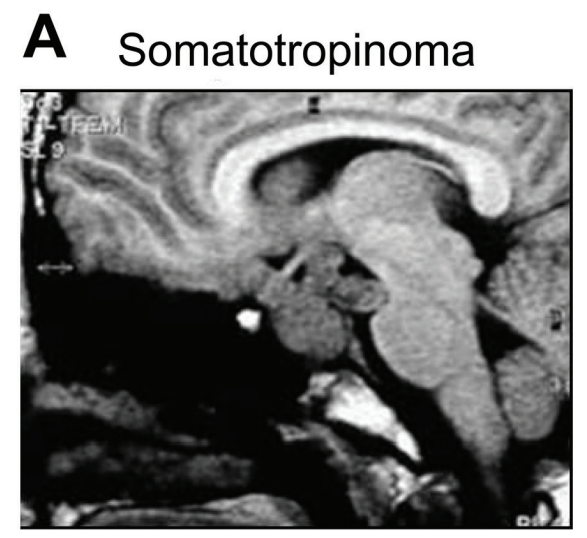

B

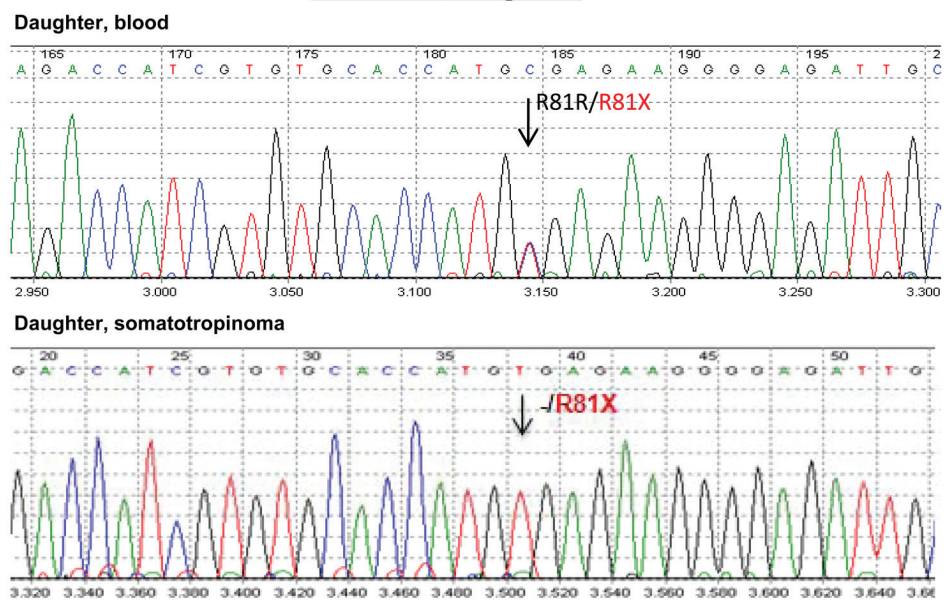

C

AIP protein expression

Normal pituitary (autopsy)

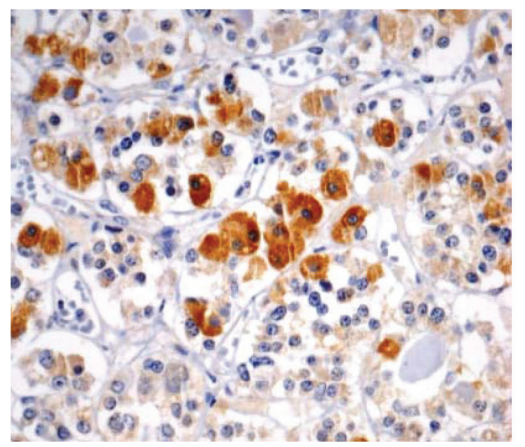

Somatotropinoma Wt $A$ IP

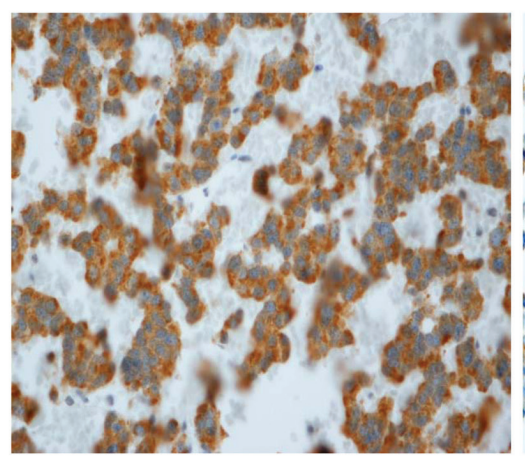

Somatotropinoma AIP R81X / LOH

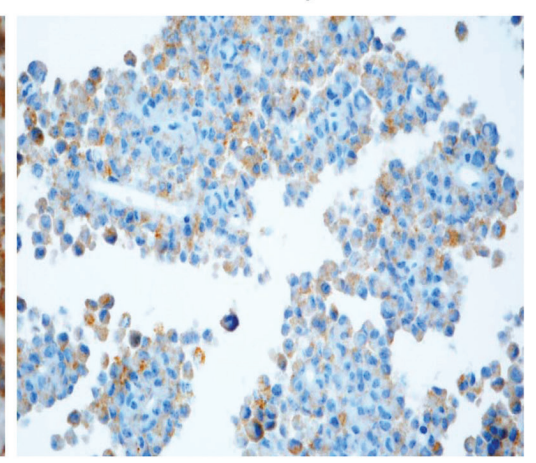

Figure 2 - Loss of AIP in the familial somatotropinoma. A - The MRI of the index patient's daughter revealed a large and invasive pituitary adenoma (somatotropinoma) that was resistant to treatment with a somatostatin analog. She inherited the heterozygous R81X AIP germline mutation (Fig. 1B) from the index case. B - The sequence analysis of AIP in tumoral DNA samples revealed that only the R81X-mutated allele (t) was present in the somatotropinoma, indicating somatic loss and inactivation of wild-type AIP. C - The immunohistochemical analysis showed AIP protein expression in the normal pituitary and a GH-secreting pituitary adenoma of a patient with sporadic acromegaly without AIP mutation. The somatotropinoma of the patient harboring the R81X germline mutation and the somatic loss of the gene presented low AIP protein expression. 
A

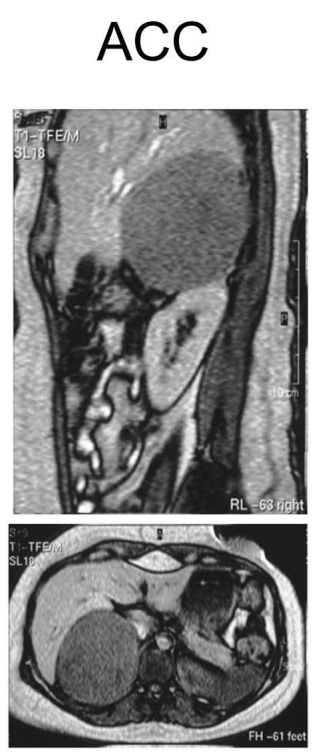

C
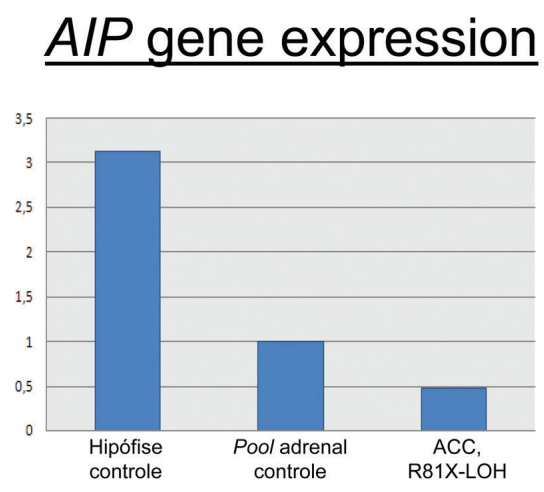

B Index-case (mother), blood

\section{$\mathrm{LOH}$ analysis}

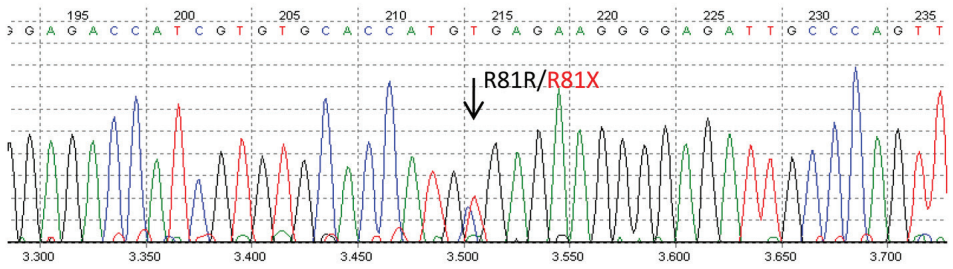

Index-case (mother), ACC

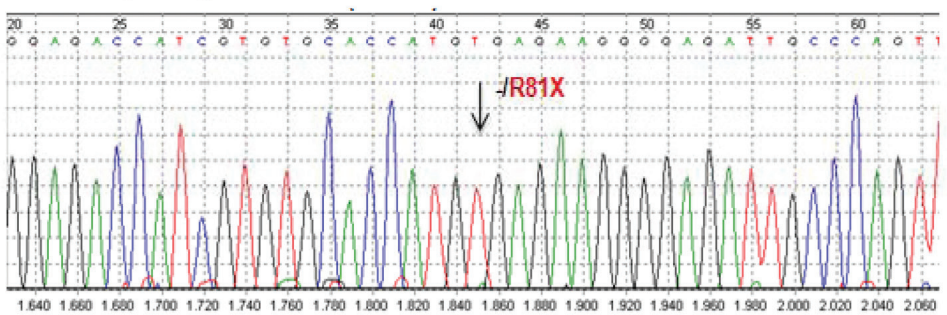

D AIP protein expression

normal adrenal (autopsy)

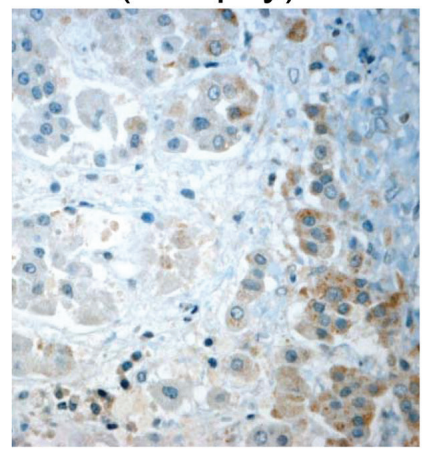

ACC
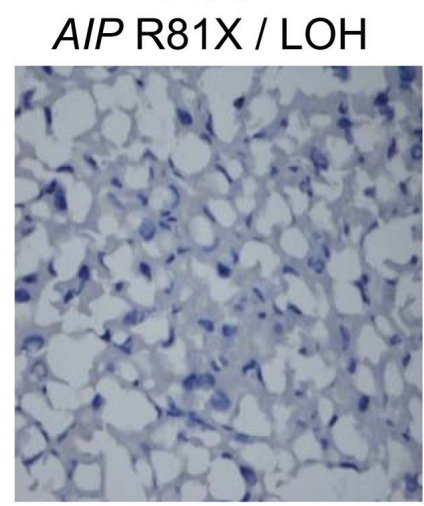

Figure 3 - Loss of AIP in the adrenocortical tumor. A - An abdominal imaging scan of the index case when she presented with virilization and high serum levels of adrenal steroids. The scan revealed a large heterogeneous mass $(9.0 \mathrm{~cm} \times 8.9 \mathrm{~cm})$ in the right adrenal gland, which was surgically excised and histopathologically classified as adrenocortical carcinoma. B - Sequence and microsatellite (D11S1258 AIP-flanking marker) analyses of DNA samples from the tumor revealed loss of the wild-type $A I P$ allele. $\mathbf{C}$ - The $2^{-\Delta \Lambda} \mathrm{CT}$ method was used to compare AIP mRNA expression in pooled normal pituitary glands $(\mathrm{Ct} \mathrm{AIP}=25.66, \mathrm{Ct} \beta$-actin=24.24), pooled normal adrenal glands $(\mathrm{Ct} \mathrm{AIP}=25.42 ; \mathrm{Ct} \beta$-actin=22.49) and the adrenocortical carcinoma from the index case, in whom the AIP wild-type allele was lost $(\mathrm{Ct} \mathrm{AIP}=31.53, \mathrm{Ct} \beta$-actin=27.28). The mean $\mathrm{Ct}$ value of the normal adrenal pool was used as a reference (1.0), by comparison, there was decreased AIP expression in the adrenocortical carcinoma (0.48). D - Immunohistochemistry using the AIP antibody showed low/ moderate staining in a normal adrenal gland obtained from autopsy. A complete loss of AIP immunoreactivity was observed in the adrenocortical carcinoma from the index patient, which stained positive for Melan A and 35betaH11, which were used as positive controls.

LOH in this non-pituitary (adrenocortical) tumor, as shown in Figure 3B.

\section{AIP immunohistochemistry}

Pituitary tissue: Decreased AIP immunostaining was observed in the pituitary adenoma from the daughter harboring the R81X germline mutation, while intense cytoplasmic AIP positivity was observed in the normal pituitary glands obtained from autopsy samples and in a somatotropinoma from a patient with sporadic acromegaly without the AIP germline mutation (Figure 2C).
Adrenal tissue: The mother's adrenocortical carcinoma showed positive staining for Melan A and 35betaH11 (data not shown), which are two markers of adrenal cortical differentiation used as positive controls, and complete loss of AIP immunoreactivity (Figure 3D). Moderate and strong staining of AIP-positive cells was observed in normal adult (Figure 3D) and infant adrenal tissue, respectively.

Grade II B-cell non-Hodgkin lymphoma: Normal AIP protein expression was observed in the index patient's B-cell lymphoma when compared to the amygdala lymphoid tissue, which was used as a control (Figure 4). 


\section{AMYGDALA (normal control)}
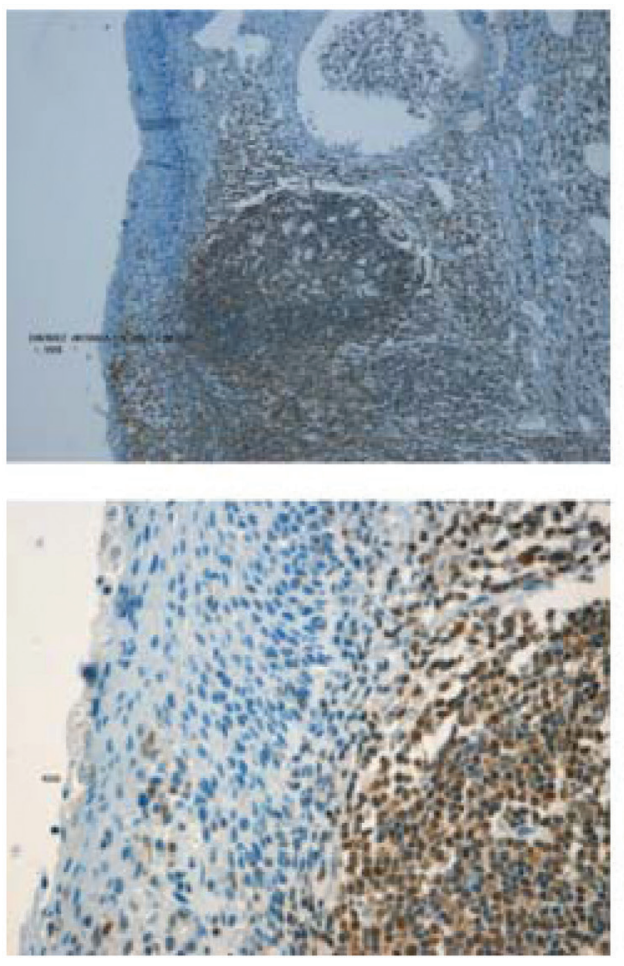

B-CELL NON-HODGKIN LYMPHOMA, GRADE 2 (index case, germiline AIP R81X
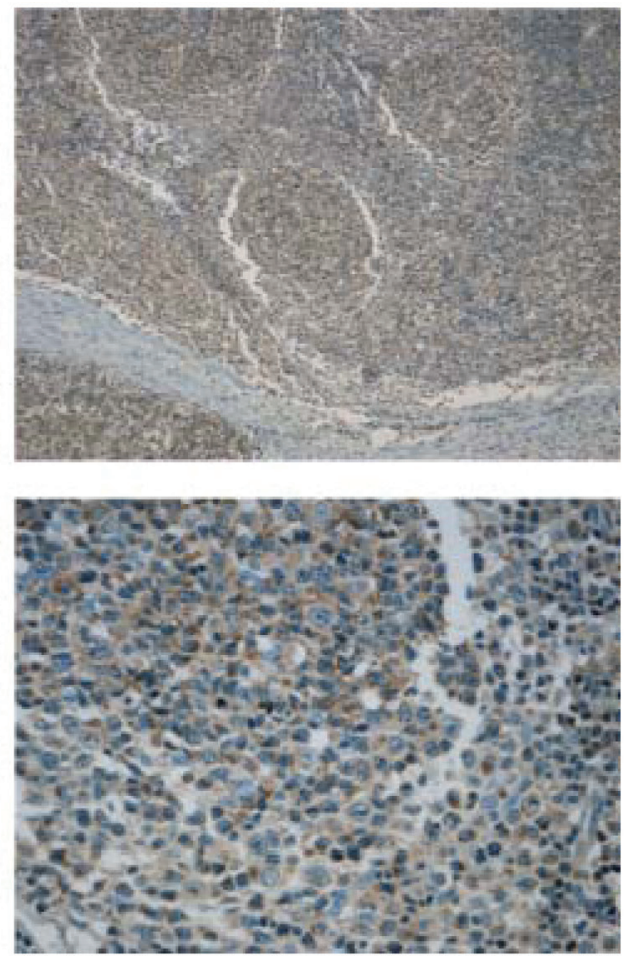

\section{$\underline{\mathrm{LOH} \text { analysis }}$}
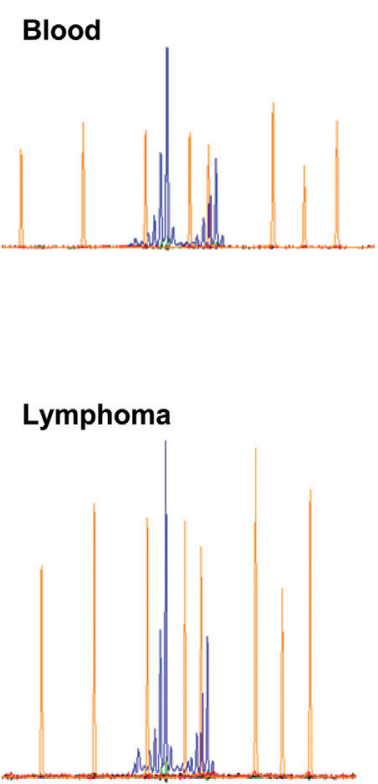

Figure 4 - Maintenance of heterozygosity and positive AIP immunostaining in the B-cell non-Hodgkin lymphoma of the R81X AIP mutated IFS patient.

\section{DISCUSSION}

Rare extra-pituitary tumors have been identified in PAP/ FIPA patients harboring AIP mutations. Mutant AIP cannot interact with cAMP-specific PDE4A and therefore is likely to disrupt the cAMP signaling pathway. ${ }^{12,27,28}$ This pathway has been previously implicated in both pituitary and nonpituitary tumorigenesis through defects in the PRKARIA, ${ }^{29}$ GNAS1, ${ }^{30} P D E 11 A^{31}$ and $P D E 8 B^{32}$ genes. Thus, further investigation of the role of $A I P$ in these concomitant nonpituitary tumors is warranted. Here, we present the first somatic investigations of pituitary and non-pituitary tumors (somatotropinoma, adrenocortical and grade II B-cell nonHodgkin lymphoma) in a family harboring an AIP germline mutation.

We initially found that both the mother and daughter with acromegaly harbored a functional cAMP pathway-disrupting germline mutation in AIP (c.241C $>\mathrm{T}$; R81X). Through sequence analysis of tumoral samples, we showed that the remaining wild-type allele $\mathrm{C}$ was lost in the daughter's GHsecreting pituitary adenoma and the mother's adrenocortical carcinoma. LOH was confirmed by analyzing the D11S1258 repeat marker located at the AIP locus (11q13.3). In addition, we observed decreased AIP mRNA and protein expression in the adrenocortical tissue when compared to normal controls (Figure 3C and 3D). In contrast, normal AIP protein expression and no $\mathrm{LOH}$ for 11q13.3 locus were verified in the B-cell non-Hodgkin lymphoma from the same patient (Figure 4). According to the Knudson twohit model, these findings confirm that AIP plays a tumor suppressor role in the pituitary, as previously reported, $, 2,3,4,8$ and suggest for the first time that $A I P$ may also be implicated in non-pituitary tumorigenesis. Interestingly, previous genetic studies have strongly suggested the existence of an as-yet-unidentified tumor suppressor gene at 11q13 that is implicated in adrenocortical tumorigenesis. ${ }^{33-35} \mathrm{We}$ are expanding the analysis of AIP to a large cohort of Brazilian sporadic adrenocortical tumors.

Of note, a reported female patient harboring a germline nonsense AIP mutation, L210X, developed a broad panel of neoplasias involving the pituitary, adrenocortical and thyroid glands $;^{10}$ this previous report suggests that the tumor susceptibility was similar to that observed in our index case. The L201X-mutated patient presented with secondary amenorrhea at the age of 25 and was diagnosed with acromegaly at 27 years of age. Subsequently, she developed a 19-mm non-secretory adrenocortical adenoma and a 4-cm thyroid adenoma. Georgitsi et al. studied 91 
cases of "MEN1-related" tumors without MEN1 mutation, and they detected 2 cases $(2.2 \%)$ with $A I P$ germline mutations. ${ }^{11}$ However, no details of the clinical manifestation of the mutated patients were provided, and it is not clear if they were FIPA/IFS patients. Recently, patients with AIP mutations and thyroid disorders, including nodular goiters, follicular adenomas and follicular and papillary thyroid carcinomas, have been described (Prof. Beckers, FIPA Workshop 2009, Liège, unpublished data; Drs. Outi Vierimaa and Pasi Salmela, University of Helsinki, Marianthi Georgitsi's PhD Thesis). In these cases, it is not known whether the non-pituitary tumors occurring in the FIPA cases harboring an AIP mutation were related to the primary germline event. Further molecular investigations in FIPA/IFS patients with non-pituitary tumors would improve our knowledge of the tumoral susceptibility caused by AIP germline defects.

In conclusion, our study presents the first molecular analysis of non-pituitary tumors in patients harboring the AIP germline mutation. The finding of somatic AIP inactivation in the adrenocortical tumor of a $A I P$-mutated patient suggests that we should further investigate the role of this recently identified tumor suppressor gene in nonpituitary tumors, especially those tumors in which cAMP and the $11 \mathrm{q} 13$ locus are implicated.

\section{REFERENCES}

1. Melmed S. Medical progress: acromegaly. N Engl J Med. 2006;355:255873.

2. Vierimaa O, Georgitsi M, Lehtonen R, Vahteristo P, Kokko A, Raitila A, et al. Pituitary adenoma predisposition caused by germline mutations in the AIP gene. Science. 2006;312:1228-30.

3. Daly AF, Vanbellinghen JF, Khoo SK, Jaffrain-Rea ML, Naves LA, Guitelman MA, et al. Aryl hydrocarbon receptor-interacting protein gene mutations in familial isolated pituitary adenomas: analysis in 73 families. J Clin Endocrinol Metab. 2007;92:1891-96

4. Soares BS, Frohman LA. Isolated familial somatotropinoma. Pituitary. 2004;7:95-101.

5. Daly AF, Tichomirowa MA, Beckers A. Genetic, molecular and clinical features of familial isolated pituitary adenomas. Horm Res. 2009;71:11622.

6. Toledo RA, Lourenco DM Jr, Liberman B, Cunha-Neto MB, Cavalcanti MG, Moyses CB, et al. Germline mutation in the aryl hydrocarbon receptor interacting protein gene in familial somatotropinoma. J Clin Endocrinol Metab. 2007;92:1934-37.

7. Barlier A, Vanbellinghen JF, Daly AF, Silvy M, Jaffrain-Rea ML, Trouillas J, et al. A () Mutations in the aryl hydrocarbon receptor interacting protein gene are not highly prevalent among subjects with sporadic pituitary adenomas. J Clin Endocrinol Metab. 2007;92:1952-5.

8. Iwata T, Yamada S, Mizusawa N, Golam HM, Sano T, Yoshimoto K. The aryl hydrocarbon receptor-interacting protein gene is rarely mutated in sporadic GH-secreting adenomas. Clin Endocrinol. 2007;66:99-502.

9. Igreja S, Chahal HS, Akker SA, Gueorguiev M, Popovic V, Damjanovic S, et al. Assessment of p27 (cyclin-dependent kinase inhibitor 1B) and aryl hydrocarbon receptor-interacting protein (AIP) genes in multiple endocrine neoplasia (MEN1) syndrome patients without any detectable MEN1 gene mutations. Clin Endocrinol, 2009;70:259-64.

10. Cazabat L, Libe R, Perlemoine K, Rene-Corail F, Burnichon N, Gimenez-Roqueplo AP, et al. Germline inactivating mutations of the aryl hydrocarbon receptor-interacting protein gene in a large cohort of sporadic acromegaly: mutations are found in a subset of young patients with macroadenomas. Eur J Endocrinol. 2007;157:1-8.
11. Georgitsi M, Raitila A, Karhu A, Tuppurainen K, Makinen MJ, Vierimaa $\mathrm{O}$, et al. Molecular diagnosis of pituitary adenoma predisposition caused by aryl hydrocarbon receptor interacting protein gene mutations. Proc Natl Acad Sci USA. 2007;104:4101-05.

12. Bolger GB, Peden AH, Steele MR, MacKenzie C, McEwan DG, Wallace DA, et al. Attenuation of the activity of the cAMP-specific phosphodiesterase PDE4A5 by interaction with the immunophilin XAP2. J Biol Chem. 2003;278:3351-63.

13. de Oliveira SK, Hoffmeister M, Gambaryan S, Muller-Esterl W, Guimaraes JA, Smolenski AP. Phosphodiesterase 2A forms a complex with the co-chaperone XAP2 and regulates nuclear translocation of the aryl hydrocarbon receptor. J Biol Chem. 2007;282:13656-63.

14. Davies H, Bignell GR, Cox C, Stephens P, Edkins S, Clegg S, et al. Mutations of the BRAF gene in human cancer. Nature. 2002;417:949-54.

15. Groussin L, Kirschner LS, Vincent-Dejean C, Perlemoine K, Jullian E, Delemer B, et al. Molecular analysis of the cyclic AMP-dependent protein kinase A (PKA) regulatory subunit 1A (PRKAR1A) gene in patients with Carney complex and primary pigmented nodular adrenocortical disease (PPNAD) reveals novel mutations and clues for pathophysiology: augmented PKA signaling is associated with adrenal tumorigenesis in PPNAD. Am J Hum Genet. 2002;71:1433-42.

16. Luccio-Camelo DC, Une KN, Ferreira RE, Khoo SK, Nickolov R, Bronstein MD, et al. A meiotic recombination in a new isolated familial somatotropinoma kindred. Eur J Endocrinol. 2004;150:643-648

17. Toledo RA, Wagner SM, Coutinho FL, Lourenço DM Jr, Azevedo JA, Longuini $\mathrm{VC}$, et al. High penetrance of pheochromocytoma associated with the novel C634Y/Y791F double germline mutation in the RET protooncogene. J Clin Endocrinol Metab. 2010;95:1318-27.

18. Lourenço DM Jr, Toledo RA, Mackowiak II, Coutinho FL, Cavalcanti MG, Correia-Deur JE, et al. Multiple endocrine neoplasia type 1 in Brazil: MEN1 founding mutation, clinical features, and bone mineral density profile. Eur J Endocrinol. 2008; 159:259-74.

19. Jorge BH, Agarwal SK, Lando VS, Salvatori R, Barbero RR, Abelin N, et al. Study of the multiple endocrine neoplasia type 1, growth hormonereleasing hormone receptor, Gs alpha, and Gi2 alpha genes in isolated familial acromegaly. J Clin Endocrinol Metab. 2001;86:542-4. 
20. Lourenço DM Jr, Toledo RA, Coutinho FL, Margarido LC, Siqueira SA, dos Santos MA, et al. The impact of clinical and genetic screenings on the management of the multiple endocrine neoplasia type 1 . Clinics. 2007;62:465-76

21. Toledo RA, Lourenco DM, Coutinho FL, Quedas E, Mackowiack I, Machado MC, et al. Novel MEN1 germline mutations in Brazilian families with multiple endocrine neoplasia type 1. Clin Endocrinol. 2007;67:377-84

22. Santos MA, Nunes AB, Abelin N, Ezabella MC, Toledo Rde A, Lourenço D M Jr, et al. Genetic screening of multiple endocrine neoplasia type 2: experience of the USP Endocrine Genetics Unit. Arq Bras Endocrinol Metabol. 2006;50:7-16.

23. Toledo SP, dos Santos MA, Toledo RA, Lourenço DM Jr. Impact of RET proto-oncogene analysis on the clinical management of multiple endocrine neoplasia type 2. Clinics. 2006;61:59-70.

24. Nunes AB, Ezabella MC, Pereira AC, Krieger JE, Toledo SP. A novel Val648Ile substitution in RET protooncogene observed in a Cys634Arg multiple endocrine neoplasia type $2 \mathrm{~A}$ kindred presenting with an adrenocorticotropin-producing pheochromocytoma. J Clin Endocrinol Metab. 2002;87:5658-61.

25. Latronico AC, Pinto EM, Domenice S, Fragoso MC, Martin RM, Zerbini $\mathrm{MC}$, et al. An inherited mutation outside the highly conserved DNAbinding domain of the p53 tumor suppressor protein in children and adults with sporadic adrenocortical tumors. J Clin Endocrinol Metab. 2001;86:4970-4973.

26. Livak KJ, Schmittgen TD. Analysis of relative gene expression data using real-time quantitative PCR and the 2(-Delta Delta C(T)) Method. Methods. 2001;25:402-408.

27. Meyer BK, Petrulis JR, Perdew GH. Aryl hydrocarbon (Ah) receptor levels are selectively modulated by hsp90-associated immunophilin homolog XAP2. Cell Stress Chaperones. 2000;5:243-254.
28. Leontiou CA, Gueorguiev M, van der Spuy J, Quinton R, Lolli F, Hassan $\mathrm{S}$, et al. The role of the aryl hydrocarbon receptor-interacting protein gene in familial and sporadic pituitary adenomas. J Clin Endocrinol Metab. 2008;93,2390-2401.

29. Landis CA, Masters SB, Spada A, Pace AM, Bourne HR, Vallar L. GTPase inhibiting mutations activate the alpha chain of Gs and stimulate adenylyl cyclase in human pituitary tumors. Nature 1989; 340:692-6.

30. Kirschner LS, Carney JA, Pack SD, Taymans SE, Giatzakis C, Cho YS, et al. Mutations of the gene encoding the protein kinase A type I-alpha regulatory subunit in patients with the Carney complex. Nature Genetics 2000; 26: 89-92.

31. Horvath A, Boikos S, Giatzakis C, Robinson-White A, Groussin L, et al. A genomewide scan identifies mutations in the gene encoding phosphodiesterase 11A4 (PDE11A) in individuals with adrenocortical hyperplasia. Nat Genet. 2006;38:794-800.

32. Horvath A, Mericq V, Stratakis CA. Mutation in PDE8B, a cyclic AMPspecific phosphodiesterase in adrenal hyperplasia. N Engl J Med. 2008;358:750-2

33. Kjellman M, Roshani L, Teh BT, Kallioniemi OP, Höög A, Gray S, et al. Genotyping of adrenocortical tumors: very frequent deletions of the MEN1 locus in 11q13 and of a 1-centimorgan region in 2p16. J Clin Endocrinol Metab. 1999;84:730-5.

34. Heppner C, Reincke M, Agarwal SK, Mora P, Allolio B, Burns AL, et al. MEN1 gene analysis in sporadic adrenocortical neoplasms. J Clin Endocrinol Metab. 1999;84:216-9.

35. Wajchenberg BL, Albergaria Pereira MA, Medonca BB, Latronico AC, Campos Carneiro P, Alves VA, et al. Adrenocortical carcinoma: clinical and laboratory observations. Cancer. 2000;88:711-36. 